\title{
Factors Affecting the Reproductive Performance of Sahiwal Cattle
}

\author{
Devesh Singh, C. B. Singh, B. S. Khadda* and S. B. Bhardwaj \\ Department of Livestock Production Management, College of Veterinary and Animal \\ Sciences, G. B. Pant University of Agriculture and Technology, Pantnagar-263145, \\ Uttarakhand, India \\ *Corresponding author
}

\section{A B S T R A C T}

\section{Keywords}

Age at first calving,

Calving interval,

Service period,

Sahiwal cattle,

Reproductive traits

\section{Article Info}

Accepted:

10 August 2020

Available Online:

10 September 2020

\begin{abstract}
The present study was conducted on 308 Sahiwal cows sired by 38 bulls spared over a period of 32 years (1981- 2012), maintained at instructional dairy farm and AICRP on cattle -Sahiwal (field unit) at G.B.P.U.A. \& T., Pantnagar Uttarakhand and Chak Ganjaria Government Cattle Farm Lucknow, Uttar Pradesh. The overall least- square means for age at first calving (AFC), first calving interval (FC1) and first service period (FSP) were $1281.89 \pm 15.57,426.70 \pm 8.53$ and $140.85 \pm 8.90$ days, respectively. Significant effect of sire and farm was observed in all the reproductive traits, while season was found to nonsignificantly influencing the age at first calving, first calving interval and first service period. Period of calving had highly significant $(\mathrm{P}<0.01)$ effect on AFC whereas, effect period of calving was found to be non-significant on first calving interval and first service period. Based on present study, it may be concluded that the optimum genetic potential for reproduction traits in Sahiwal cattle may be exploited by following proper feeding, management practices and adopting strict diseases control measure throughout the year and season.
\end{abstract}

\section{Introduction}

Cattle are the most important livestock in India and play a vital role in agriculture economy. Total cattle population in India is 192.49 million and the highest contribution is from Non-Descript category of animals which is $73.83 \%$ of the total Indigenous cattle. Out of the remaining $26.17 \%, 4.2 \%$ contribution is from Haryana breed followed by Gir and Sahiwal contributed over 3\% each of total indigenous cattle (Breed Survey, 2013 and Livestock Census 2019). Sahiwal is considered as the best milch dairy breed of the country and is well adapted to the tropical and sub tropical conditions. It is recognized by various names as Lola, Montgomery, Lambi-Bar and Multani. The original breeding tract of this breed is in the central and southern area of Punjab particularly in Montgomery district in Pakistan. Small herd of Sahiwal cattle are found along the IndoPak borders of Ferozpur and Amritsar districts of Punjab and Sri Ganganagar district in Rajasthan. Sahiwal is known for low maintenance cost, high milk constituents, 
disease resistance and endurance to hot climatic conditions of tropics. Total Sahiwal population in India is $4,88,294.00$ which is the second highest cattle population of India after Haryana (Breed Survey, 2013). The selection of the superior animals with maximum accuracy is of utmost importance for any breed improvement programme where performances of first lactation traits are of utmost importance. In present Investigation an attempt was made to evaluate the reproductive performance of Sahiwal cows maintained at multi-locational herds and to estimate their genetic parameters.

\section{Materials and Methods}

The data for present investigation on 308 Sahiwal cows were collected from pedigree cum history sheets of three herds namely Instructional Dairy Farm (IDF) of Govind Ballabh Pant University of Agriculture and Technology Pantnagar (Uttarakhand), Chak Ganjaria Government Cattle Farm Lucknow (Uttar Pradesh), and animal maintained under All India Coordinated Research Project (AICRP) on Cattle Sahiwal under field condition nearby area of Pantnagar (Uttarakhand).The data set were spread over a period 32 years(1981-2012), at a class interval of 8 years and only first lactation records were considered for investigation. Each year was further delineated into three seasons were rainy (July- October), winter (NovemberFebruary) and summer (March-June). The first reproduction traits under investigation were Age at first calving (AFC), first calving interval (FC1) and first service period (FSP). The effect of various genetic and non-genetic factors on different traits were further analyzed using mixed model least-squares and maximum likelihood computer program (LSMLMW PC-1 version) for fitting constant to overcome the difficulty of disproportionate sub class frequencies and non- orthogonality of data designed by Harvey (1990). The difference between means was tested for significance by Duncan's multiple range test (Kramer, 1957). Paternal half-sib correlation method was used to estimate heritability as described by Hazel \& Terril (1945). The standard error of heritability was estimated by using the formula as given by Swiger et al., (1964).

\section{Results and Discussion}

The overall least squares means for age at first calving (AFC), first calving interval (FC1) and first service period (FSP) were $1281.89 \pm 15.57,426.70 \pm 8.53$ and $140.85 \pm 8.90$ days, respectively (Table 1). The results are in agreement with results reported by Banik (2004), Manoj (2009) and Raja (2010) in Sahiwal cattle. However, higher estimates of FCI than the present study were reported by Bhoj (2012) and Singh and Singh (2016).

The effect of sire was found to be significant $(\mathrm{P}<0.05)$ on age at first calving (AFC), first calving interval (FC1) and first service period (FSP) indicating the existence of additive genetic variability among these traits which can be used effectively for further improvement and selection of superior sire could be effective for the improvement of these traits.

The effect of farm was highly significant $(\mathrm{P}<0.01)$ on age at first calving $(\mathrm{AFC})$, first calving interval (FC1) and first service period (FSP). These results are in close agreement with finding of Vinoo et al., (2005) in Ongole cattle. Cows at Chak Ganjaria Government cattle farm had highest age at first calving (AFC), first calving interval (FC1) and first service period (FSP) with their mean value $1313.22 \pm 26.12,481.30 \pm 14.15$ and $197.54 \pm$ 14.76 days, respectively. Whereas, cows reared at field condition had lowest AFC, FCI and FSP with their mean value $1243.19 \pm$ $34.39,379.59 \pm 18.71$ and $97.73 \pm 19.51$ 
days, respectively. The lower level of traits in at field condition may be may be due to individual care and better managemental practices.

The effect of season of calving was nonsignificant on age at first calving (AFC), first calving interval (FC1) and first service period (FSP). Cows calving during winter season had more age at first calving $(1290.55 \pm 19.84$ days), first calving interval $(435.34 \pm 10.75)$ and first service period (FSP) $(149.60 \pm 11.21$ days) whereas; rainy calvers had less FCI $(418.60 \pm 11.52$ days) and FSP (132.68 \pm 12.01 days).

The non-significant effect of season of calving on AFC, FCL and FSP were also reported by Singh et al., (2005) and Manoj et al., (2012) and Singh and Singh (2016).

Table.1 Least-squares means and their standard error for various reproductive traits in Sahiwal cattle

\begin{tabular}{|l|c|c|c|c|}
\hline Source of Variation & No of obs. & AFC (Days) & FCI (Days) & FSP (Days) \\
\hline Overall mean & 308 & $1281.89 \pm 15.57$ & $426.70 \pm 8.53$ & $140.85 \pm 8.90$ \\
\hline Sire & & $*$ & $*$ & $*$ \\
\hline Season & & NS & NS & NS \\
\hline Summer & 109 & $1271.73 \pm 18.76$ & $426.17 \pm 10.19$ & $140.26 \pm 10.63$ \\
\hline Rainy & 86 & $1283.38 \pm 21.25$ & $418.60 \pm 11.52$ & $132.68 \pm 12.01$ \\
\hline Winter & 113 & $1290.55 \pm 19.84$ & $435.34 \pm 10.75$ & $149.60 \pm 11.21$ \\
\hline Period & & $*$ & NS & NS \\
\hline $\mathbf{1 9 8 1}$ to 1988 & 191 & $1304.32^{\mathrm{a}} \pm 22.27$ & $443.22 \pm 12.06$ & $156.83 \pm 12.58$ \\
\hline $\mathbf{1 9 8 9}$ to 1996 & 20 & $1368.14^{\mathrm{a}} \pm 35.74$ & $436.95 \pm 19.49$ & $153.21 \pm 20.33$ \\
\hline $\mathbf{1 9 9 7}$ to 2004 & 17 & $1236.09^{\mathrm{b}} \pm 39.60$ & $410.36 \pm 21.54$ & $122.81 \pm 22.47$ \\
\hline $\mathbf{2 0 0 5}$ to 2012 & 80 & $1219.00^{\mathrm{b}} \pm 19.77$ & $416.28 \pm 10.99$ & $130.51 \pm 11.46$ \\
\hline Farm & & $*$ & $*$ & $*$ \\
\hline LKO & 169 & $1313.22^{\mathrm{a}} \pm 26.12$ & $481.30^{\mathrm{a}} \pm 14.15$ & $197.54^{\mathrm{a}} \pm 14.76$ \\
\hline IDF & 106 & $1289.25^{\mathrm{b}} \pm 15.95$ & $419.23^{\mathrm{b}} \pm 8.64$ & $127.27^{\mathrm{b}} \pm 9.01$ \\
\hline Field & 33 & $1243.19^{\mathrm{c}} \pm 34.39$ & $379.59^{\mathrm{c}} \pm 18.71$ & $97.73^{\mathrm{c}} \pm 19.51$ \\
\hline
\end{tabular}

Note: Estimates with different superscripts differ significantly. F statistic of corresponding effects as $* *=$ highly significant $(\mathrm{P}<0.01), *=$ Significant $(\mathrm{P}<0.05), \mathrm{NS}=$ Non-significant. AFC- age at first FCI- First Calving Interval and FSP - First Service Period

Table.2 Estimates of heritability with their standard error for various production traits in Sahiwal cattle

\begin{tabular}{|c|l|c|}
\hline Sl. & \multicolumn{1}{|c|}{ Traits } & Heritability $\left(\mathbf{h}^{\mathbf{2}} \pm\right.$ S.E. $)$ \\
\hline 1. & Age at first calving (AFC) & $0.45 \pm 0.12$ \\
\hline 2. & First Calving Interval (FCI) & $0.25 \pm 0.07$ \\
\hline 3. & First Service Period (FSP) & $0.25 \pm 0.09$ \\
\hline
\end{tabular}

Period of calving had highly significant $(\mathrm{P}<0.01)$ effect on AFC whereas, effect period of calving was found to be non- significant on first calving interval (FC1) and first service period (FSP). The differences among period could be due to management 
practices followed during the different periods and varied climatic conditions. These results are in close agreement with findings of Singh et al., (2005), Manoj et al., (2012) and Singh and singh (2016) in Sahiwal cattle.

The heritability estimates were $0.45 \pm 0.12$, $0.25 \pm 0.07$ and $0.25 \pm 0.09$ for age at first calving (AFC), first calving interval (FC1) and first service period (FSP), respectively (Table 2). The heritability estimate for AFC was moderate to high whereas, the heritability estimates for FCI and FSP were observed to be low to moderate.

The similar reports were also reported by Singh et al., (2005) and Kumar et al., (2010). However, Manoj (2009) and Singh and Singh (2016) reported lower values of heritability for AFC trait. The moderate value of heritability of AFC indicate sufficient genetic base that can be utilized by selecting the animals for lower AFC. The lower to moderate value of heritability indicated that the traits are influenced mainly by nongenetic factors and could be improved by better feeding practices and managemental conditions. Some improvement in the trait can be made by selecting the cows for these traits.

In conclusion the low to moderate heritability among reproduction traits indicated that the presence of genetic variance and the selection can be applied to improve these traits to some extent along with following good managemental practices. Optimum genetic potential for reproduction traits in dairy cattle may be exploited by following proper feeding, management practices and adopting strict diseases control measure throughout the year and season. The significant effect of nongenetic factors like period and farm may be attributed to the non-uniform feeding system and management practices followed in different farms during the study period.

\section{Acknowledgement}

The authors are thankful to the Director Experiment, G. B. Pant University of Agriculture \& Technology, Pantnagar, Uttarakhand for encouragement and providing facilities for the study.

\section{References}

Banik, S. 2004. Sire evaluation in Sahiwal cattle. Ph.D. Thesis, NDRI Deemed University, Karnal, India.

Bhoj, S. 2012. Performance evaluation of reproduction and production traits of Sahiwal cows under farm conditions M.V.Sc. thesis, G.B. Pant University of Agriculture and Technology, Pantnagar, India.

Breed survey, 2013. Estimated livestock population breed wise survey 2013. Government of India, Ministry of agriculture \& farmers welfare, Department of animal husbandry, dairying \& fisheries, (Animal husbandry statistics division) Krishi Bhawan, New Delhi.

Harvey, W.R. 1990. User guide for LSMLMW and MIXMDL package. Mix Model Least Squares and Maximum Likelihood Computer Programme. $\quad P C-2 \quad$ Version Mimeograph, Columbia, Ohio, USA.

Hazel, L.N. and Terrill, C.E. 1945. Heritability of weaning weight and stable length in range Rambouillet lambs. Journal of Animal Science, 4:347-358.

Kramer, C. V. (1957). Extension of multiple range tests to group mean with unequal number of replications. Biometric: 12:307-310.

Livestock Census, 2019. The 20 ${ }^{\text {th }}$ Livestock Census, 2019. Ministry of Fisheries, Animal Husbandry and Dairying, Government of India, Krishi Bhawan, 
New Delhi.

Manoj, M. 2009. Evolving multi-trait selection criteria using body weights and first lactation traits in Sahiwal cattle. M.V.Sc. Thesis, NDRI, Karnal, India.

Manoj, M., Gandhi, R. S., Raja, T.V., Singh, A. and Sachdeva, G.K. 2012. Effect of non genetic factors on the first lactation production and reproduction performance in Sahiwal cattle. Indian journal of Dairy Science, 65 (3): 264265.

Raja, K.N. 2004. Genetic and phenotypic trends for production and reproductjo11 performance of Sahiwal cattle. M.V.Sc. Thesis, NDRI Deemed University Karnal, India.

Singh, V.K., Singh, C.V., Kumar, D. and
Kumar, A. 2005. Genetic evaluation of some economic traits in Sahiwal and its crosses. Indian J. Dairy Sci., 58 (3): 206-210.

Singh, J. and Singh, C.V. 2016. Genetic and phenotypic parameters of first lactation and life time traits in Sahiwal cows J. Vet. Sci. Tech., 7 (4): 345.

Swiger, L. A., Harvery, W. R., Everson, D. O. and Gregory, K. E. 1964. The variance of intra- class correlation involving groups with one observation. Biometrics 20: 818 .

Vinno, R., Narsimharao, G., Gupta, B.R. and Rao, K.B. 2005. Genetic study on production and reproduction traits of Ongole cattle. Indian J. Anim. Sci., 74 (4): 438-44.

\section{How to cite this article:}

Devesh Singh, C. B. Singh, B. S. Khadda and Bhardwaj, S. B. 2020. Factors Affecting the Reproductive Performance of Sahiwal Cattle. Int.J.Curr.Microbiol.App.Sci. 9(09): 1236-1240. doi: https://doi.org/10.20546/ijcmas.2020.909.151 